University of Nebraska - Lincoln

DigitalCommons@University of Nebraska - Lincoln

January 2005

\title{
ORYCTOANTIQUUS BOREALIS, NEW GENUS AND SPECIES FROM THE EOCENE OF OREGON, U.S.A., THE WORLD'S OLDEST FOSSIL DYNASTINE AND LARGEST FOSSIL SCARABAEID (COLEOPTERA: SCARABAEIDAE: DYNASTINAE)
}

Brett C. Ratcliffe

University of Nebraska-Lincoln, bratcliffe1@unl.edu

Dena M. Smith

University of Colorado Museum of Natural History, Dena.Smith@colorado.edu

D Erwin

dmerwin@uclink4.berkeley.edu

Follow this and additional works at: https://digitalcommons.unl.edu/entomologypapers

Part of the Entomology Commons

Ratcliffe, Brett C.; Smith, Dena M.; and Erwin, D, "ORYCTOANTIQUUS BOREALIS, NEW GENUS AND SPECIES FROM THE EOCENE OF OREGON, U.S.A., THE WORLD'S OLDEST FOSSIL DYNASTINE AND LARGEST FOSSIL SCARABAEID (COLEOPTERA: SCARABAEIDAE: DYNASTINAE)" (2005). Papers in Entomology. 34.

https://digitalcommons.unl.edu/entomologypapers/34

This Article is brought to you for free and open access by the Museum, University of Nebraska State at DigitalCommons@University of Nebraska - Lincoln. It has been accepted for inclusion in Papers in Entomology by an authorized administrator of DigitalCommons@University of Nebraska - Lincoln. 


\title{
Oryctoantiques borealis, New Genus and Species from the Eocene of Oregon, U.S.A., the World's Oldest Fossil Dynastine and Largest Fossil Scarabaeid (Coleoptera: Scarabaeidae: Dynastinae)
}

\author{
BRetT C. RatClifFe \\ Systematics Research Collections \\ W-436 Nebraska Hall \\ University of Nebraska \\ Lincoln, NE 68588-0514, U.S.A. \\ bratcliffe1@unl.edu \\ Dena M. SMith \\ University of Colorado Museum of Natural History \\ UCB 265, University of Colorado \\ Boulder, CO 80309, U.S.A. \\ Dena.Smith@colorado.edu \\ AND \\ DiANE ERWIN \\ Museum of Paleontology \\ 1101 Valley Life Sciences Bldg. \\ University of California \\ Berkeley, CA 94720, U.S.A. \\ dmerwin@uclink4.berkeley.edu
}

We don't know one millionth of one percent about anything.

—Thomas Edison

\begin{abstract}
Oryctoantiquus borealis Ratcliffe and Smith is described as a new genus and new species of fossil dynastine Scarabaeidae from West Branch Creek of the Middle Eocene Clarno Formation (44.6-46.8 Ma) of north-central Oregon, U.S.A. This specimen is the oldest specimen attributable to the subfamily Dynastinae and the largest fossil in the family Scarabaeidae.
\end{abstract}

The Scarabaeoidea is one of the largest superfamilies of beetles with approximately 2,200 genera and about 31,000 species (Jameson and Ratcliffe 2002). In the Nearctic Realm there are about 170 extant genera and 2,000 species (Jameson and Ratcliffe loc. cit.). Nearly all of today's genera were probably established by the Miocene (Howden 1966), and living species of beetles are probably not older than the Pleistocene (Crowson 1981), although Coope (1979) suggested some may extend back to the Late Tertiary. Coope (1979) and Matthews (1980) observed that fossil Coleoptera from the Late Miocene (5.7 Ma) fall outside the range of variation of living species but are often so close that many of them could be considered "ancestral" to present day species.

Krell (2000) cataloged 238 fossil species, subspecies, and ichnofossils of Scarabaeoidea from Mesozoic and Tertiary deposits. Krell considered 27 of those 
"species" as dubious, and eight species were previously identified as representing other taxa. Thus, 203 species and 12 ichnospecies reliably belong to the superfamily Scarabaeoidea.

The oldest fossils attributed to the Scarabaeoidea (Aphodiites from Switzerland) are from the Lower Jurassic (Arnol'di et al. 1977), but Krell (2000) argued that there is no clear evidence that these fossils are actually scarabaeoids. Ponomarenko (1995) suggested a minimum age for Scarabaeoidea as Middle Jurassic, but the fossil evidence from this time is not reliable. Holcorobeus nigrimontanus Nikolajev (1992), from the Upper Jurassic of Kazakhstan, is probably the oldest fossil that is unequivocally a scarabaeoid based on the form of the legs and coxae. Krell (2000), however, disagreed and gave that distinction to a specimen from the Lower Cretaceous Santana Formation in Brazil that shows lamellate antennae, which is THE distinguishing character for Scarabaeoidea. Lawrence et al. (2000) stated that, in the absence of lamellate antennae, it is possible to assign a fossil to the superfamily Scarabaeoidea by means of coxal and leg structures.

The scarabaeid subfamily Dynastinae today contains some of the most spectacular insects on Earth because of the large size and extravagant horns in the males of some species. There are approximately 1,500 species of extant Dynastinae (Endrödi 1985), but only six fossil dynastines have been named, and these were all described between 1862 and 1914 (Heer 1862; Heyden and Heyden 1866; Weyenbergh 1869; Wickham 1911, 1914). Of these, Krell (2000) believed that Pentodon proserpinae (Heer) (Miocene, Germany) and Oryctes pluto Weyenbergh (Jurassic, Germany) were not scarabaeids. Thus, four fossils can be assigned to the Dynastinae: Tomarus compositus (Wickham), T. effetus (Wickham), Strategus cessatus Wickham (all Late Eocene, Florissant, CO, U.S.A.) and Pentodon bellerophon Heyden and Heyden (Oligocene, Germany).

Scholtz and Chown (1995) reported that no fossils of the higher scarabaeids are known from before $50 \mathrm{Ma}$ and that this lineage diversified no earlier than about $65 \mathrm{Ma}$. The higher scarabaeids represent a shift from (adult) humus-feeding ancestors in a soil habitat to adult-feeding on roots, leaves, flowers, fruit, and sap, This change seems to have been precipitated by the Cretaceous-Early Paleogene radiation of angiosperms (Scholtz and Chown 1995) that completely changed the landscape in terms of available food niches for insects. The oldest recorded higher scarabaeid, Eophyllocerus Haupt, 1950 (assigned to Melolonthinae) is from 40 Ma Eocene "brown coal" deposits in Germany (Crowson 1981; Scholtz 1995).

Accordingly, we are very excited to describe here what is now the oldest fossil of a higher scarabaeid that dates from the explosion of the pleurostict scarabaeid lineage during the Tertiary. This new fossil that we place in the subfamily Dynastinae probably occurs near the base of Dynastinae evolution, at least as we imperfectly understand it today. We describe here a large fossil dynastine scarabaeid beetle from West Branch Creek, Middle Eocene (44.6-46.8 Ma) Clarno Formation of north-central Oregon, U.S.A. This specimen is also the largest known scarabaeid fossil ( $\mathrm{ca} .50 \mathrm{~mm}$ in length). The fossil is a ventral mold of a jumbled portion of the mesosternum and mesocoxal cavities (slightly offset from the reminder of the fossil), a nearly complete metasternum, left metepimeron and trace of the right, both metacoxae, both posterior femora, right tibia, and partial trace of the left tibia.

\section{Oryctoantiquus Ratcliffe and Smith, new genus}

Type Species. Oryctoantiquus borealis Ratcliffe and Smith.

Diagnosis. The same as for the monotypic species, Oryctoantiquus borealis. The pattern of punctures on the metasternum, combined with the large body size and form 


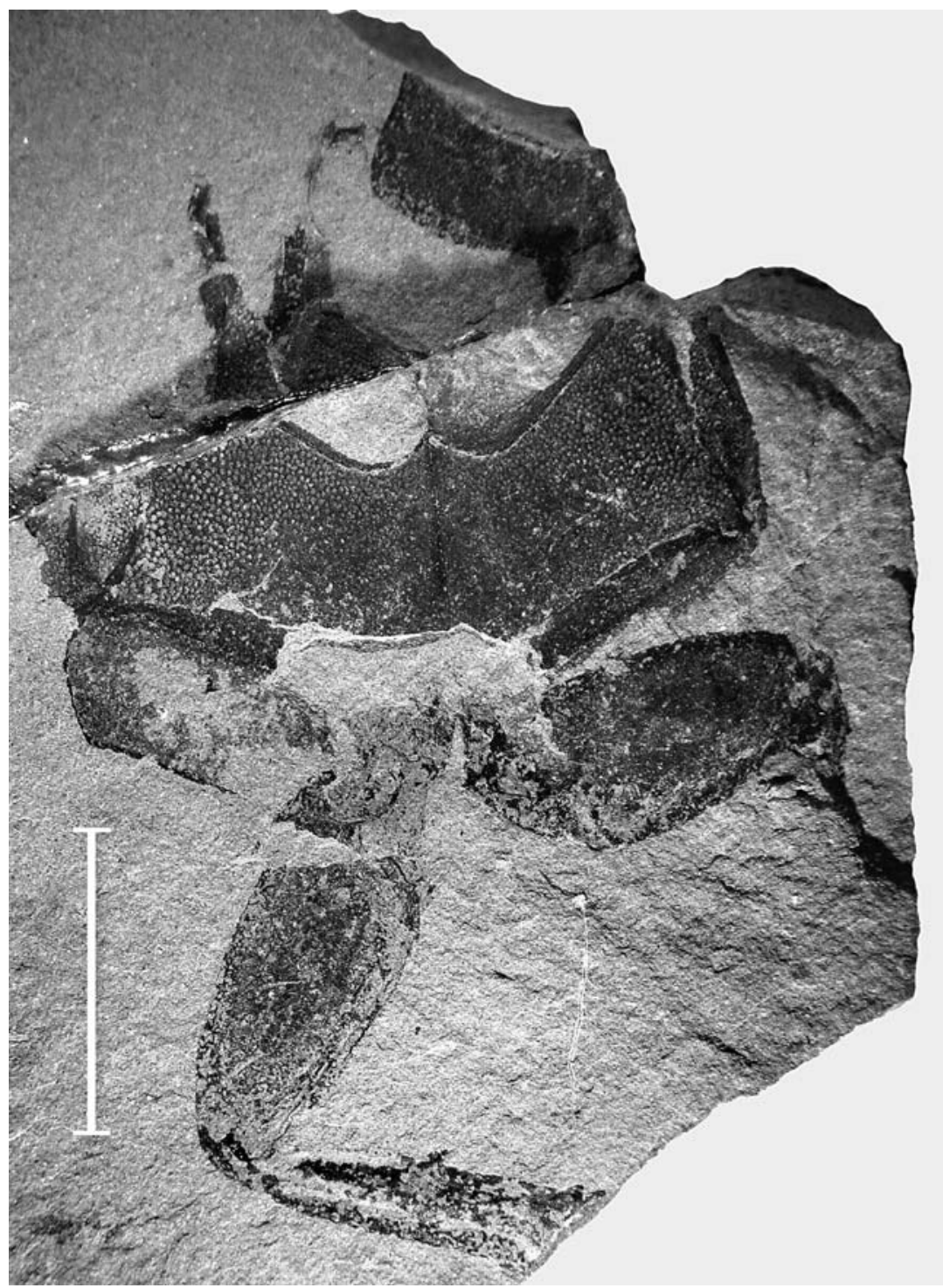

Fig. 1. Oryctoantiquus borealis. Scale bar equals $10 \mathrm{~mm}$.

of the posterior legs, distinguishes Oryctoantiquus from other genera in the tribe Oryctini.

Etymology. The generic name is derived from the Greek oryktes, meaning digger (also the stem of the dynastine tribal name Oryctini), and the Latin antiquus, meaning old; hence the "old digger" or "old oryctine" in reference to the 45 million year old age of the fossil and the tribe to which we assign it. 


\section{Oryctoantiquus borealis Ratcliffe and Smith, new species}

(Figs. 1-2)

Type Material. Holotype labeled UCMP (University of California Museum of Paleontology) PA503//157049. Holotype deposited at the Museum of Paleontology, University of California, Berkeley, CA.

Occurrence. Middle Eocene, Clarno Formation, West Branch Creek, Wheeler County, Oregon, U. S. A. UCMP locality 3904, USGS locality 8637, UF locality 230.

Diagnosis. Metasternum proportionately large, transverse $(19 \mathrm{~mm}$ wide, $6.9 \mathrm{~mm}$ long along central, longitudinal sulcus); surface punctate on lateral half of each side; punctures dense, moderate in size (Figs. 1-2). Metepimeron similarly punctate. Mesocoxal cavities (coxae not present) and metacoxae large, transverse ( $\mathrm{ca} .2 .5 \times 9.0$ $\mathrm{mm})$, contiguous at midline. Posterior femora enlarged $(c a .6 .1 \times 12.4 \mathrm{~mm})$ (division between trochanter and femur not evident). Right posterior tibia apically widened, with apparent small, lateral tooth near middle and another small, lateral tooth at apex; longest length $11.5 \mathrm{~mm}$.

Etymology. The species name is derived from the Latin borealis, in reference to the northerly locality of the species; most oryctine species today are southerly in their distribution because their habitats are mostly subtropical or tropical.

Classification. Ratcliffe compared the fossil with extant species of Scarabaeoidea. Aside from the fact that $O$. borealis is much larger than any of those compared, it still did not resemble any species of Passalidae, Lucanidae, Geotrupidae, Pleocomidae, Trogidae, or Scarabaeidae (Scarabaeinae, Melolonthinae, Rutelinae, or Cetoniinae). Oryctoantiquus borealis is unique among fossil scarabs, and the few leg and sternum characters it possesses allow us to confidently place it with the tribe Oryctini in the subfamily Dynastinae. Characters that place it in the tribe Oryctini are (1) the enlarged femora, (2) apically expanded posterior tibiae that are toothed at their apices, (3) large, transverse, coxal cavities, (4) large metasternum with distinctive punctation on the anterolateral surface, and (5) large size and robust body form. The Oryctini today contains mostly larger $(20-70 \mathrm{~mm})$ scarabs in 26 genera with 230 species. Species in the tribe occur worldwide except for Australia and the northernmost parts of Europe, Asia, and North America.

The metasternum and legs of $O$. borealis (Fig. 2) bear a strong resemblance to those of the extant Strategus aloeus (L) (Fig. 3), a species that is found from the southern United States to South America. And yet they are different. We postulate that $O$. borealis is not congeneric with Strategus Hope since Strategus is South American in origin and spread northwards into Central and North America (Ratcliffe 1976) only after the establishment of the isthmus of Panama in the Miocene about 7.1 Ma (Coates 2004). Oryctoantiquus borealis was already established in northwestern North America 46-44 Ma, a full 39-37 million years before ancestral Strategus species entered North America. Furthermore, the metasternum in all extant species of Strategus is either entirely punctate or, more typically, with the anterior half punctate (Fig. 3). The metasternum of $O$. borealis has a different pattern of sculpturing where the punctures are broadly separated along the midline (Fig. 2).

Using the assumption that northwestern North America may have been more broadly joined with Asia $45 \mathrm{Ma}$, we also considered the possibility of affinities with Asian genera of Oryctini whose ancestors may have dispersed to North America. Ratcliffe examined extant genera of Asian oryctines to determine if $O$. borealis could be considered congeneric with any of them. Species of Oryctes Illiger, Trichogomphus Burmeister, Scapanes Burmeister, Clyster Arrow, and Dichodontus Arrow were examined, and none resembled $O$. borealis in size, proportions, or punctation pattern.

Of the four fossil taxa currently placed in the subfamily Dynastinae, three (two 


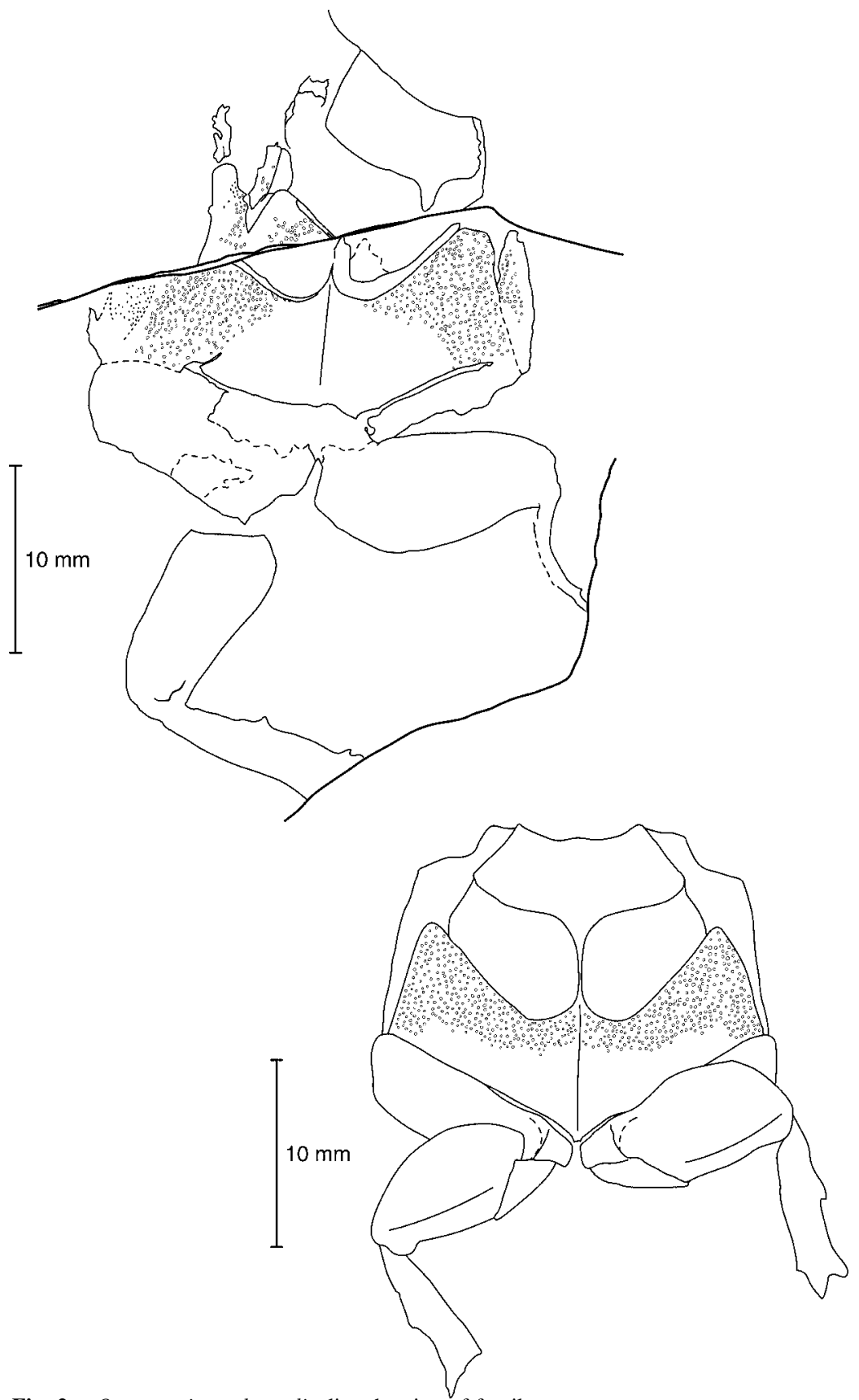

Fig. 2. Oryctoantiquus borealis, line drawing of fossil.

Fig. 3. Strategus aloeus, line drawing of extant species in same position as that of fossil Oryctoantiquus borealis. 
Tomarus species and the single Pentodon species) are in the tribe Pentodontini, and one (Strategus cessatus Wickham) is placed in the Oryctini. Strategus cessatus is known from a single wing cover from the late Eocene (34 Ma) Florissant shales in Colorado. The Florissant climate at this time was temperate to warm temperate (Gregory 1994; Gregory and Chase 1992; Meyer 1992, 2003; Wolfe 1992a, 1994, 1998) although a few subtropical to tropical taxa are found in the assemblage (Moe and Smith, in review), which is in keeping with the climate requirements of extant Strategus species. Ratcliffe examined the specimen (Ratcliffe 1976) and concluded that it did most closely resemble the extant Strategus cessus LeConte from Arizona. Whether the Florissant fossil represents the genus Strategus is now doubtful, especially considering that it predates the establishment of the Panamanian isthmus, which was the dispersal route of ancestral Strategus from South America to North America. As Krell (2000) noted, “... most Tertiary fossil Scarabaeoidea were classified in an extant genus because the latter resembles the shape of the fossil and was known to the classifying author. In most of these cases, the fossil does not show any diagnostic character of the extant genus, much less any generic autapomorphy." While the specimen of Oryctoantiquus is 15 million years older than $S$. cessatus and is a larger and more robust beetle, we have no way of knowing if they are congeneric because there is not enough of each specimen preserved to provide sufficient evidence. But we do believe that Oryctoantiquus is a distinct genus based upon its size, puncture pattern on the metasternum, and location in time and space.

Size. The largest fossil in the superfamily Scarabaeoidea is a stag beetle (family Lucanidae), Protognathinus spielbergei Chalumeau and Brochier, from the Eocene (49 Ma) oil shale deposits of Messel, Germany (Hoffmann 2000; Chalumeau and Brochier 2001). It is $55.0 \mathrm{~mm}$ in length. The largest known fossil in the family Scarabaeidae up until now was Cheirotonus otai Ueda (1989) (subfamily Euchirinae) from the Middle Miocene of Japan. This specimen is $45.0 \mathrm{~mm}$ long from the apex of the clypeus to the apex of the abdomen. We believe that Oryctoantiquus borealis is now the largest fossil specimen in the family Scarabaeidae. The proportions of posterior tibial length do not differ significantly among Dynastinae and especially in members of the Oryctini, which are robust and compact beetles adapted for digging. The posterior tibial length of $O$. borealis is $11.5 \mathrm{~mm}$ whereas the posterior tibial length of $C$. otai is $9.2 \mathrm{~mm}$. Extrapolating from many specimens of the abundant Strategus aloeus (L.) (a modern oryctine analog occurring from the southern U.S. to South America; Fig. 3) with the same posterior tibial length as that of $O$. borealis, we arrive at a body length (apex of clypeus to apex of abdomen) for $O$. borealis of $50.0 \mathrm{~mm}$, or $5.0 \mathrm{~mm}$ longer than C. otai.

Geological Setting. The West Branch Creek fossil locality is west of the town of Mitchell, Oregon. The laminated shales have limited exposure and are primarily found along a tributary that drains into the West Branch Creek. This locality is a lacustrine deposit from the middle Eocene Clarno Formation (Manchester 1990; Meyer and Manchester 1997). Although the Clarno Formation consists primarily of volcanigenic sediments that range in age from 39-54 million years, the localities that yield insect and plant fossils are usually composed of mixed-debris flow deposits, tuff beds and lacustrine units (Bestland et al. 1999). Major collections of West Branch Creek plant material have been made in the past and include leaves, fruits, seeds, and flowers. The flora includes many subtropical plant taxa, including a fossil banana (Musaceae) (Manchester and Kress 1993). Although a few insects, primarily beetles, have been collected from the West Branch Creek locality, none of them have been described before.

Fossils from the Clarno Formation record an important interval in the Tertiary of North America. During the Eocene and Oligocene, there was dramatic change in climate from generally warm and tropical to much cooler and temperate. This transition is well-documented in both the marine and terrestrial fossil record (Berggren and 
Prothero 1992) and is especially pronounced in the Pacific Northwest where it appears that mean annual temperatures may have declined by approximately $8^{\circ} \mathrm{C}$ (Wolfe $1992 \mathrm{~b}$ ), and the mean annual range in temperature may have increased by as much as $15^{\circ} \mathrm{C}$ (Wolfe 1978). The habitat of Oryctoantiquus borealis would have been forests that are most similar to modern subtropical and tropical forests (Wing 1998; Manchester and Meyer 1987). After the Eocene-Oligocene cooling event, forests of the Pacific Northwest became much more temperate, hosting a combination of conifers, broad-leaved evergreens, and deciduous plant taxa (Wing 1998). Oryctoantiquus and its lineage began to attenuate and ultimately become extinct because the new, temperate climate and habitat could not support a tropical lineage.

\section{Acknowledgments}

BCR thanks Angie Fox (Scientific Illustrator, University of Nebraska State Museum) for the line illustrations and Matt Paulsen (University of Nebraska) for the photograph of the fossil. Mary Liz Jameson (University of Nebraska), Clarke Scholtz (University of Pretoria) and Frank-Thorsten Krell (The Natural History Museum, London) provided valuable commentary and constructive criticism to improve the manuscript. Robert Hunt (University of Nebraska) provided valuable information on the fossil sites in Oregon. This project was supported, in part, by an NSF/PEET grant (DEB-0118669) to M. L. Jameson and B. C. Ratcliffe and an NSF/BS\&I grant (DEB9870202) to B. C. Ratcliffe and R. D. Cave. DMS thanks S. R. Manchester for an introduction to the exceptional fossil floras of Oregon and access to the West Branch Creek assemblage.

\section{Literature Cited}

Arnol'di, L. V., V. V. Zherikhin, L. M. Nikritin, and A. G. Ponomerenko. 1977. Mesozoic Coleoptera. Akademiya Nauk SSSR, Trudy Paleontologicheskogo Instituta, Volume 161:1-255, 14 plates (1992 translation of Mezozoiskie Zhestkokrylye. Smithsonian Institution Libraries and the National Science Foundation, Washington, D.C.).

Berggren, W. A., and D. R. Prothero. 1992. Eocene-Oligocene climatic and biotic evolution: an overview [pp. 1-28]. In: Eocene-Oligocene climatic and biotic evolution prothero (D. R. and W. A. Berggren, editors). Princeton University Press, Oxford.

Bestland, E. A., R. E. Hammond, D. L. S. Blackwell, M. A. Kays, G. J. Retallack, and J. Stimac. 1999. Geologic framework of the Clarno Unit, John Day Fossil Beds National Monument, central Oregon. Oregon Geology 61:3-19.

Chalumeau, F., and B. Brochier. 2001. Une forme fossil nouvelle de Chiasognathinae: Protognathinus spielbergei (Coleoptera, Lucanidae). Lambillionea 101:593-595.

Coates, A. G. 2004. The Panama land bridge. Missouri Botanical Garden $51^{\text {st }}$ Annual Systematics Symposium. Abstracts, p. 22-23.

Coope, G. R. 1979. Late Cenozoic fossil Coleoptera: evolution, biogeography, and ecology. Annual Review of Ecology and Systematics 10:247-267.

Crowson, R. A. 1981. The biology of the Coleoptera. Academic Press, London. 802 pp.

Endrödi, S. 1985. The Dynastinae of the World. Dr. W. Junk Publishers, Dordrecht. 800 pp., 46 plates.

Gregory, K. M. 1994. Paleoclimate and paleoelevation of the 35 Ma Florissant flora, Front Range, Colorado. Palaeoclimates 1:23-57.

Gregory, K. M., and C. G. Chase. 1992. Tectonic significance of paleobotanically estimated climate and altitude of the late Eocene erosion surface, Colorado. Geology 20:581-585.

Haupt, H. 1950. Die Käfer (Coleoptera) aus der eozänen Braunköhle des Geiseltales. Geologica 6(VIII):1-168.

Heer, O. 1862. Beiträge zur Insektenfauna Oeningens. Coleoptera. Geodaphagen, Hydrocanthariden, Gyriniden, Brachelytren, Clavicornen, Lamellicornen und Buprestiden. 
Natuurkundige Verhandlelingen van de Hollandsche Maatschappij der Wetenschappen te Haarlem 16:1-90.

Heyden, C. von, and L. von Heyden. 1866. Käfer und Polypen aus der Braunkohle des Siebengebirges. Palaeontographica 15:131-156.

Hoffmann, H. J. 2000. Messel. Window on an ancient world. National Geographic Magazine 197:34-51.

Howden, H. F. 1966. Some possible affects of the Pleistocene on the distributions of North American Scarabaeidae (Coleoptera). Canadian Entomologist 98:1177-1190.

Jameson, M. L., and B. C. Ratcliffe. 2002. Series Scarabaeiformia Crowson 1960, Superfamily Scarabaeoidea Latreille 1802 [pp. 1-5]. In: American beetles, Volume 2 (R. H. Arnett, M. Thomas, P. E. Skelley, and J. H. Frank, editors). CRC Press, Boca Raton, FL. 861 pp.

Krell, F. T. 2000. The fossil record of Mesozoic and Tertiary Scarabaeoidea (Coleoptera: Polyphaga). Invertebrate Taxonomy 14:871-905.

Lawrence, J. F., A. M. Hastings, M. J. Dalwitz, T. A. Paine, and E. J. Zurcher. 2000. Beetles of the World: a key and information system for families and subfamilies. CSIRO Publishing, Melbourne (CD-ROM).

Manchester, S. R. 1990. Eocene to Oligocene floristic changes recorded in the Clarno and John Day formations, Oregon, USA [pp. 183-187]. In: Symposium Proceedings, Paleofloristic and Paleoclimatic Changes in the Cretaceous and Tertiary (E. Knobloch and Z. Kvacek, editors). Geological Survey Press, Prague, Czechoslovakia.

Manchester, S. R., and W. J. Kress. 1993. Fossil bananas (Musaceae), Ensete oregonense sp nov, from the Eocene of western North American and its phytogeographic significance. American Journal of Botany 80:1264-1272.

Manchester, S. R., and H. W. Meyer. 1987. Oligocene fossil plants of the John Day Formation, Fossil, Oregon. Oregon Geology 49:115-127.

Matthews, J. V., Jr. 1980. Tertiary land bridges and their climate: backdrop for development of the present Canadian insect fauna. The Canadian Entomologist 112:1089-1103.

Meyer, H. W. 1992. Lapse rates and other variables applied to estimating paleoaltitudes from fossil floras. Palaeogeography, Palaeoclimatology, and Palaeoecology 99:71-99.

Meyer, H. W. 2003. The fossils of Florissant. Smithsonian Books, Washington, D. C. 258 pp.

Meyer, H. W., and S. R. Manchester. 1997. The Oligocene Bridge Creek flora of the John Day Formation, Oregon. University of California Publications in Geological Sciences 141: 1-195, 75 plates. University of California Press, USA.

Moe, A. P., and D. M. Smith. (In Press). Using pre-Quaternary Diptera as indicators of paleoclimate. Palaeogeography, Palaeoclimatology, and Palaeoecology.

Nikolajev, G. V. 1992. Taksonomicheskie priznaki i sostav rodov mezozoiskikh zhukov (Coleoptera, Scarabaeidae). Paleontologicheskii Zhurnal 1992:76-88.

Ponomarenko, A. G. 1995. The geological history of beetles [pp. 155-171]. In: Biology, phylogeny, and classification of Coleoptera. Papers Celebrating the $80^{\text {th }}$ Birthday of Roy A. Crowson (J. Pakaluk and S. A. Ślipinśki, editors). Muzeum i Instytut Zoologie PAN, Warsaw, Poland.

Ratcliffe, B. C. 1976. A revision of the genus Strategus (Coleoptera: Scarabaeidae). Bulletin of the University of Nebraska State Museum 10:1-204.

Scholtz, C. H. 1990. Phylogenetic trends in the Scarabaeoidea (Coleoptera). Journal of Natural History 24:1027-1066.

Scholtz, C. H., and S. L. Chown. 1995. The evolution of habitat use and diet in the Scarabaeoidea: a phylogenetic approach [pp. 355-374]. In: Biology, phylogeny, and classification of Coleoptera. Papers Celebrating the $80^{\text {th }}$ Birthday of Roy A. Crowson (J. Pakaluk and S. A. Ślipinśki, editors). Muzeum i Instytut Zoologie PAN, Warsaw, Poland.

Ueda, K. 1989. A Miocene fossil of long-armed scarabaeid beetle from Tottori, Japan. Bulletin of the Kitakyushu Museum of Natural History 9:105-110.

Weyenbergh, H. 1869. Sur les insectes fossiles du calcaire lithographique de la Bavière, qui se trouvent au Musée Teyler. Archives du Musée Teyler 2:247-294.

Wickham, H. F. 1911. Fossil Coleoptera from Florissant, with descriptions of several new species. Bulletin of the American Museum of Natural History 30:53-69.

Wickham, H. F. 1914. New Miocene Coleoptera from Florissant. Bulletin of the Museum of Comparative Zoology 58:421-494. 
Wing, S. L. 1998. Tertiary vegetation of North America as a context for mammalian evolution [pp. 37-65]. In: Evolution of Tertiary mammals of North America, Vol. 1: terrestrial carnivores, ungulates, and ungulatelike mammals (C. M. Janis, K. M. Scott, and L. J. Jacobs, editors). Cambridge University Press, Cambridge, UK.

Wolfe, J. A. 1978. A paleobotanical interpretation of Tertiary climates in the northern hemisphere. American Scientist 66:694-703.

Wolfe, J. A. 1992a. An analysis of present-day terrestrial lapse rates in the western conterminous United States and their significance to paleoaltitudinal estimates. U.S. Geological Survey Bulletin 1964:35.

Wolfe, J. A. 1992b. Climatic, floristic, and vegetational changes near the Eocene/Oligocene boundary in North America [pp. 421-436]. In: Eocene-Oligocene climatic and biotic evolution (D. R. Prothero and W. A. Berggren, editors). Princeton University Press, Oxford.

Wolfe, J. A. 1994. Tertiary climatic changes at middle latitudes of western North America. Palaeogeography, Palaeoclimatology, and Palaeoecology 108:195-205.

Wolfe, J. A., C. E. Forest, and P. Molnar. 1998. Paleoecologic, paleoclimatic and evolutionary significance of the late Oligocene Creede flora, Colorado. Paleobiology 15:180-198.

(Received 16 June 2004; accepted 16 December 2004. Full page charges borne by the authors. Publication date 19 April 2005.) 